\title{
A política como "arte de matar a vergonha": o desembarque de Sirinhaém em 1855 e os últimos anos do tráfico para o Brasil
}

\author{
Marcus Joaquim Maciel de Carvalho ${ }^{1 *}$ \\ ${ }^{1}$ Universidade Federal de Pernambuco, Recife/PE - Brasil \\ Paulo Henrique Fontes Cadena ${ }^{2 *}$ \\ ${ }^{2}$ Universidade Católica de Pernambuco, Recife/PE - Brasil
}

\section{RESUMO}

Em 1855, um navio negreiro desembarcou em Pernambuco. A maioria dos cativos foi apreendida, mas uns 50 desapareceram entre os engenhos próximos, bem como a tripulação, após o capitáo conversar com um delegado e senhor de engenho, elogiado pelo cônsul inglês e por uma liderança liberal pela maneira generosa como administrava seus cativos. Também foram indiciados outros proprietários vinculados ao presidente da província e aos senadores Cavalcanti, gerando protestos ingleses e um escândalo político e diplomático que alcançou o parlamento e o gabinete da conciliação, cujo ministro da justiça, Nabuco de Araújo, havia iniciado sua carreira em Pernambuco, à sombra dos Cavalcanti. O caso revela detalhes das resilientes malhas do tráfico na política imperial.

Palavras-chave: tráfico de escravos; administração dos escravos; saquaremas; guabirus; historiografia.

DOI: http://dx.doi.org/10.1590/2237-101X02004206

Artigo recebido em 19 de junho de 2018 e aceito para publicação em 2 de novembro de 2018.

* Professor da Universidade Federal de Pernambuco / Centro de Filosofia e Ciências Humanas / Departamento de História, Recife/PE - Brasil. E-mail: marcus.carvalho.ufpe@hotmail.com. ORCID: https://orcid. org/0000-0003-1912-2879.

** Professor da Universidade Católica de Pernambuco / Departamento de História, Recife/PE - Brasil. E-mail: cadenapaulo@gmail.com. ORCID: https://orcid.org/0000-0002-6178-3665. 


\title{
Politics as the "art of ending one's shame": the 1855 Sirinhaém case and the last years of the slave trade to Brazil
}

\begin{abstract}
In 1855, a slave ship landed in Pernambuco. Most captives were arrested, but fifty disappeared into nearby plantations and the crew escaped after the captain talked to a local plantation owner. This man, who was also a police chief, received praise from the British consul and a liberal leader for the generous way he managed his slaves. Other landowners related to the president of the province and the Cavalcanti senators were indicted, which provoked British protests and a political and diplomatic scandal that reached the parliament and the conciliation cabinet, whose minister of justice, Nabuco de Araújo, had started his career as a Cavalcanti protegée. This case unveils details of the resilient links between slave trade and imperial politics.
\end{abstract}

Keywords: slave-trade; management of slaves; saquaremas; guabirus; historiography.

\section{La política como "arte de matar la vergüenza": el desembarque de Sirinhaém en 1855 y los últimos años del tráfico para Brasil}

\section{RESUMEN}

En 1855, un navío negrero desembarcó en Pernambuco. La mayoría de los cautivos fueron aprehendidos, pero unos 50 desparecieron entre los ingenios próximos, bien como la tripulación, después del capitán conversar con un delegado y señor de ingenio, elogiado por el cónsul inglés y por un liderazgo liberal por la manera generosa en que administraba a sus cautivos. También fueron indiciados otros propietarios vinculados al presidente de la provincia y a los senadores Cavalcanti, generando protestas inglesas y un escándalo político y diplomático que alcanzó el parlamento y el gabinete de la conciliación, cuyo ministro de justicia, Nabuco de Araújo, inició su carrera en Pernambuco a la sombra de los Cavalcanti. El caso revela detalles de las resistentes mallas del tráfico en la política imperial.

Palabras clave: tráfico de esclavos; administración de los esclavos; saquaremas; guabirus; historiografía.

Em outubro de 1855, um navio negreiro foi capturado em Sirinhaém, Pernambuco. Lembra Leslie Bethell que já haviam se passado uns três anos sem notícia de algum desembarque eficaz. Haveria ainda algumas tentativas posteriores, mas foi em Sirinhaém o último 
desembarque comprovado. ${ }^{1} \mathrm{O}$ barco trazia 240 a 250 pessoas de Angola, a maioria crianças, das quais umas 200 sobreviveram. Quase 50 desapareceram, distribuídas entre senhores de engenho de Sirinhaém, onde havia engenhos do clã Cavalcanti e até do ex-regente Araújo Lima, o Marquês de Olinda. Foi um escândalo político e diplomático que reverberou até o trono atingindo as relaçôes com a Inglaterra, que havia deixado de invadir os portos brasileiros, passando a clamar em favor dos africanos livres ainda não emancipados e das pessoas trazidas da África depois de 1831 e, portanto, ilegalmente escravizadas. Para Joaquim Nabuco, na "triste história da diplomacia do tráfico, talvez não haja nota mais dura do que a de Jerningham a Paranhos em 7 de março de 1856". ${ }^{2}$

Esse episódio revelou as malhas que ligavam o "gabinete da conciliação" com o tráfico e algumas das fissuras no campo saquarema que se preparava para enfrentar a "eleição dos círculos" de 1856. ${ }^{3}$ Como há muito indicou Peter Eisenberg, nos últimos anos do tráfico, alguns navios procuraram Pernambuco por ser uma rota menos vigiada. $\mathrm{O}$ episódio de Sirinhaém mostra como se davam os desembarques nas praias que margeavam alguns dos principais engenhos da província, cujos proprietários participavam ativamente nesse ramo de negócios. Revela ainda uma parte das redes atlânticas desse tráfico a partir de Pernambuco, que alcançava, inclusive, os Estados Unidos. Ficaram claras, ainda, as malhas que ligavam esses senhores de engenho-traficantes à elite imperial, chegando ao ministro da Justiça do gabinete da conciliação e seus aliados do clã Cavalcanti, que formava uma verdadeira bancada familiar no senado imperial, como veremos nas páginas seguintes.

$\mathrm{Na}$ noite de 11 de outubro de 1855, o capitáo de um navio negreiro apareceu no engenho Trapiche, do Coronel Gaspar Menezes de Vasconcellos Drummond, anunciando a chegada do barco, ancorado na ilha de Santo Aleixo, em frente à praia que margeava o engenho. Segundo o cônsul inglês e a imprensa de oposição, Drummond recusou a carga humana mas não tinha força armada para fazer a apreensão. Enquanto esperava ajuda, a tripulação fugiu, e dezenas de africanos foram levados pelo consignatário do barco, um senhor de engenho vinculado aos Cavalcanti que, como há muito disse Taunay, foi o clã que mais senadores teve no Império do Brasil. ${ }^{4}$ O Coronel Drummond apreendeu os 165 africanos que ainda estavam na praia, onde o barco encalhou. Segundo essa versão, o governo provincial ignorou os avisos ingleses de um possível desembarque ao sul do Recife. Drummond, licenciado do posto de delegado desde 1849, não tinha como impedir a fuga da tripulação nem o desaparecimento dos africanos. O navio chegou em 10 de outubro,

\footnotetext{
${ }^{1}$ Em janeiro de 1856, a Mary Smith foi apreendida em alto-mar, antes de aportar na Bahia. Assim, foi em Sirinhaém o último desembarque comprovado. BETHELL, Leslie. The abolition of the Brazilian slave trade, Cambridge: Cambridge University Press, 1970, p. 372-374.

${ }^{2}$ NABUCO, Joaquim. Um estadista do Império: Nabuco de Araújo, sua vida, suas opiniôes, sua época. Rio de Janeiro, Garnier, 1897, v. 1, p. 232.

${ }^{3}$ Sobre a eleição dos círculos, veja-se: CARVALHO, José Murilo. A construção da ordem e Teatro de Sombras, p. 398-399; e SOARES DE SOUZA, Francisco Belisário. O sistema eleitoral no Império, passim.

${ }^{4}$ TAUNAY. O Senado no Império. 1891. Brasília: Senado Federal, 1978, p. 167.
} 
o capitão visitou Drummond no dia 11, mas o presidente, negligente, só mandou uma corveta da marinha no dia 17.

O presidente da província, José Bento da Cunha Figueiredo (futuro Visconde de Bom Conselho), contestou essa versão. Admitiu que o Coronel Drummond não era o consignatário do barco, mas podia ter agido com vigor pois era suplente do delegado licenciado. Como não fez, os africanos e a tripulação desapareceram, e alguns dos africanos ficaram com o filho de Drummond. Outros serviram de propina para autoridades locais ou chegaram até o consignatário do navio, um senhor de engenho ligado ao clã Cavalcanti. Como Drummond era senhor de quatro engenhos, com centenas de dependentes, não podia alegar que não dispunha de força armada. Assim, segundo essa versão, ele fora conivente, e seu filho culpado, junto com o consignatário do barco, o Coronel João Manoel de Barros Wanderely e um outro senhor de engenho dali perto, José Francisco de Accioli Lins.

Essa controvérsia gerou um imbróglio diplomático e político, aludido na Fala do Trono de 1856, discutido no parlamento, debatido em ácida correspondência entre Paranhos (futuro Rio Branco) e o governo inglês. Foi assunto de discurso do presidente do gabinete de ministros, Honório (Marquês do Paraná) e apareceu na correspondência do ministro da Justiça, Nabuco de Araújo, com seus aliados. Relembrado por Pedro II anos depois, o desembarque de Sirinhaém ainda seria o tema de um subcapítulo de dez páginas de Um estadista do Império, de Joaquim Nabuco, autor, digamos assim, da versão oficial dessa história.

Uma coisa se sabia: a elite imperial estava envolvida. Do Presidente da Província ao ministro da Justiça, familiares próximos de senadores, parlamentares e abastados senhores de engenho que recebiam navios negreiros em suas praias particulares. As acusaçóes recíprocas formavam um jogo de espelhos no qual todos se viam refletidos. A questão não era apenas legal, nem restrita a Pernambuco, pois, no meio da confusão, estava a complicada relação entre os saquaremas e seus aliados, os "guabirus" de Pernambuco, no momento da eleição dos círculos, que renovaria o parlamento. Agravando o quadro, logo morreria Honório, em 1856, e a epidemia do cólera prosseguia, matando cativos que não podiam mais ser repostos pelo tráfico. O desembarque de Sirinhaém expôs ainda algumas nuanças das relaçóes entre o ex-regente Araújo Lima (Marquês de Olinda), os três irmãos Cavalcanti no senado imperial (Holanda, Visconde de Albuquerque; Francisco, Visconde de Suassuna; e Pedro, Visconde de Camaragibe), o ministro da Justiça, Nabuco de Araújo, e o presidente do conselho de ministros, Honório (Paraná).

José Bento da Cunha Figueiredo já presidia Pernambuco quando Honório formou o "gabinete da conciliação", em setembro de 1853, tendo Nabuco de Araújo como ministro da Justiça. Honório, José Bento e Nabuco de Araújo conheciam bem Pernambuco. Honório como presidente, pois recebeu de Pedro II a difícil missão de pacificar a província depois da

\footnotetext{
${ }^{5}$ Esse foi o apelido dado pelos praieiros a seus adversários, os conservadores de Pernambuco.
} 
Insurreição Praieira. ${ }^{6}$ José Bento e Nabuco de Araújo estudaram Direito em Olinda, cujo diretor era o próprio Araújo Lima (Olinda). Foram colegas de Eusébio de Queirós, formado em 1832, do principal líder praieiro, Nunes Machado, e de Sérgio Teixeira de Macedo, um primo de Eusébio que sucederia o próprio José Bento no governo de Pernambuco, em 1856. Em 1838, formou-se Álvaro Barbalho Uchoa Cavalcanti, um Cavalcanti ligado ao desembarque de 1855 que, depois de uma trajetória típica do modelo de José Murilo de Carvalho, chegaria ao senado pelo "partido Cavalcanti", em $1871 .^{7}$

Nabuco de Araújo, ministro da Justiça em 1855, iniciou a carreira à sombra dos Cavalcanti. Embora seu pai fosse senador, "pouco podia ele valer ao filho", admitiu Joaquim Nabuco ao biografá-lo. ${ }^{8}$ Recém-formado, tornou-se promotor, depois, juiz no Recife. Escrevia na imprensa "guabiru" (os conservadores de Pernambuco) e ingressou na aristocracia local, a quem já servia, ao casar, em 1837, com uma sobrinha do abastado Marquês do Recife (Francisco Paes Barreto), primo dos Cavalcanti. Um "casamento brilhante", nas palavras de Jeffrey Needell, ou um golpe do baú, segundo os praieiros. Em 1838, apoiou a campanha eleitoral de Holanda (um dos três irmãos Cavalcanti) para regente do império, contra o outro pernambucano, o candidato vencedor, Araújo Lima. Em 1842, Nabuco de Araújo estava na Assembleia Provincial, em 1843, no parlamento imperial. Entre 1837 e 1844, o Baráo da Boa Vista, Francisco do Rego Barros (senador em 1850), presidia Pernambuco. Era primo em primeiro grau dos Cavalcanti e aliado político de Araújo Lima. Quando os praieiros assumiram o governo provincial, em 1845, Nabuco de Araújo já era um dos principais publicistas panfletários guabirus e assim continuaria até a Insurreição Praieira $(1848 / 49) .{ }^{9}$

O primeiro diretor da Faculdade de Direito de Olinda, Araújo Lima, continuou no cargo na década de 1830, mesmo morando na corte a maior parte de sua longa carreira política. Entre os professores de Nabuco de Araújo, José Bento e Eusébio, estava Pedro Francisco de Paula Cavalcanti de Albuquerque (Visconde de Camaragibe), diretor da Faculdade a partir de 1854. Pedro e seus irmáos, Antonio ("Holanda", nos Anais do Parlamento e Visconde de Albuquerque) e Francisco (Visconde de Suassuna), como vimos, entrariam no senado imperial. Araújo Lima e os Cavalcanti, portanto, controlavam a faculdade de Direito, onde Eusébio e outras futuras lideranças partidárias estudaram. Não sabemos como essa relação entre estudantes e professores reverberou na futura convivência parlamentar. Mas o controle

\footnotetext{
${ }^{6}$ NABUCO, Joaquim. Um estadista do Império, op. cit., p. 142; NEEDELL, Jeffrey. The party of order: the conservatives, the State and slavery in the Brazilian Monarchy, 1831-1871. Stanford: Stanford University Press, 2006. p. 163-164.

${ }^{7}$ Sobre os colegas de Nabuco de Araújo na Faculdade, veja-se: NABUCO, Joaquim. Um estadista do Império, op. cit., p. 14-15; e SISSON, S.A. Galeria dos brasileiros ilustres. V. I e II. (Rio de Janeiro, 1861) Brasília: Senado Federal, 1999, passim.

${ }^{8}$ NABUCO, Joaquim. Um estadista do Império, op. cit., p. 44.

${ }^{9}$ NEEDELL, Jeffrey. The party of order, op. cit., p. 181. NABUCO, Um estadista do Império, op. cit., p. 46.
} 
sobre a faculdade, certamente, era parte da estratégia de poder dos "guabirus", os conservadores de Pernambuco. ${ }^{10}$

José Bento, o Presidente em 1855, também advogou, inclusive a favor do conhecido negociante de escravos "Antonio da Silva e Companhia" em um caso de tráfico, em 1837. ${ }^{11}$ Conhecia bem o assunto, portanto. Professor da Faculdade de Direito a partir de 1836, chegou ao parlamento em 1847, sempre à sombra dos Cavalcanti. Tal como Nabuco de Araújo, José Bento combateu os praieiros que governaram Pernambuco durante o "quinquênio liberal" (1844-48). Depois de se destacar no ataque aos praieiros na imprensa, Nabuco de Araújo aceitou ser o juiz do processo que massacraria os rebeldes em 1849, não fosse a anistia imperial. Joaquim Nabuco fez um malabarismo retórico tentando explicar essa atitude do pai, a seu ver, sempre justo e ético. ${ }^{12} \mathrm{O}$ cavalcantismo de Nabuco de Araújo seria recompensado. O de José Bento também. A volta dos conservadores ao poder, em abril de 1848, alavancou suas carreiras. Em julho de 1850, José Bento já presidia Alagoas. ${ }^{13}$ Em 1851, Nabuco de Araújo presidiria São Paulo. Quando José Bento assumiu Pernambuco, em 1853, Nabuco de Araújo era ministro da Justiça e ressaltou sua confiança nele, "homem nosso, conhece a província e nos conhece". ${ }^{14}$

Em 1855, dois irmãos Cavalcanti já eram senadores: Holanda e Francisco. Mas, na província, quem liderava o clã era o mais moço, Pedro, o ex-professor de Nabuco de Araújo, Eusébio e José Bento. Em 1855, Pedro já era Barão (depois Visconde) de Camaragibe e Diretor da Faculdade. Senador em 1869, completou o único caso de três irmãos senadores e viscondes no império. Não era simples a relação entre os irmãos (Holanda, Francisco e Pedro) e Araújo Lima. Eram aliados quase sempre. Mas nem sempre. Araújo Lima nasceu rico e foi um dos poucos brasileiros a completar o doutorado em Coimbra, lembrou Needell, o que explica sua luta para fundar a Faculdade de Direito de Olinda, de onde deriva seu título de nobreza. Participou das constituintes de Portugal (1821) e do Brasil (1823). Junto aos Cavalcanti defendeu a "causa do Rio de Janeiro", entre 1820 e 1822, ganhando a confiança de Pedro I, que o fez ministro já em 1823. Foi o quarto candidato a regente em 1835, com 760 votos contra os 2.251 de Holanda (Cavalcanti). O vencedor, Feijó, com 2.836, indicou Araújo Lima para o Senado, mesmo com menos votos que os Cavalcanti na lista tríplice de

\footnotetext{
${ }^{10}$ MOSHER, Jeffrey. Political struggle, ideology, and state building: Pernambuco and the construction of Brazil, 1817-1850. Lincoln \& London: University Nebraska Press, 2008, cap. 5. Sobre os Cavalcanti, veja-se: CADENA, Paulo Henrique Fontes. O vice-rei: Pedro de Araújo Lima e a governança do Brasil no século XIX. Tese (Doutorado em História Social). Programa de Pós-Graduação em História - UFPE, Recife, 2018. ${ }^{11}$ Arquivo da Faculdade de Direito do Recife (AFDR), Correspondências expedidas (1830-1838), n. 1.481. Documento n. 3, outubro de 1837.

${ }^{12}$ NABUCO, Joaquim. Um estadista do Império, op. cit., p. 108-110.

${ }^{13}$ Relatório de José Bento da Cunha Figueiredo, 05/05/1850, fl. 1. http://brazil.crl.edu/bsd/bsd/16/000003. html

${ }^{14}$ Veja-se o discurso de 06 de julho de 1853. In: Hemeroteca Digital da Biblioteca Nacional (HDBN), Annaes do Parlamento Brazileiro - Câmara dos Senhores Deputados (APB), sessão de 1853. Rio de Janeiro: Typographia Parlamentar, 1876, p. 86.
} 
Pernambuco. Regente interino em 1837, efetivou-se em 1838, com 4.308 votos, seguido de Holanda, com 1.981, e de Antonio Carlos, com 597.15

Como "guabirus", os conservadores de Pernambuco, Araújo Lima e os Cavalcanti defendiam interesses comuns contra a oposição local, ou até diante dos saquaremas na corte, mas não formavam um bloco monolítico. Todavia, uma vez regente, Araújo Lima indicou, sucessivamente, Holanda e Francisco para o Senado. Apesar de guabiru em Pernambuco, Holanda flertava com os liberais na corte, assim, mal se delineavam os partidos, havia um senador Cavalcanti liberal, Holanda, e outro conservador, Francisco, justificando a máxima praieira: em Pernambuco ou se era Cavalcanti ou cavalgado. ${ }^{16}$ A influência dessa aliança oligárquica extrapolou a província, que, apesar de sua crescente inexpressividade econômica, estaria sobre-representada nos ministérios do segundo reinado através de Araújo Lima e dos Cavalcanti. Estiveram em vários ministérios entre 1840 e 1871, e ninguém foi mais vezes ministro no império do que o longevo Araújo Lima (1793-1870). ${ }^{17}$

Foi na regência de Araújo Lima que o núcleo duro saquarema (Honório, Paulino, Rodrigues Torres e Eusébio) consolidou seu poder. Numa eleição para senador pelo Rio de Janeiro, todavia, os saquaremas preferiam Clemente, ou até Calmon. O regente, todavia, nomeou seu amigo pernambucano, Lopes Gama (Visconde de Maranguape), mais conhecido como irmáo do "Padre Carapuceiro" (o padre Lopes Gama) do que por seus feitos no Senado. Joaquim Nabuco comentou os atritos de Araújo Lima com os saquaremas, que não confiavam nas oligarquias das "províncias do norte", escorando-se nos favores do trono para se contrapor às "províncias do sul”. Mais de uma vez, os conservadores de Pernambuco, os guabirus, confrontaram os saquaremas por não respaldarem suas demandas. Segundo Joaquim Nabuco, foi o próprio Paulino (Uruguai) quem fomentou o surgimento de uma oposição local, da qual derivou o futuro partido praieiro, que se rebelaria em $1848 .{ }^{18}$

Em 1849, Honório foi designado para presidir Pernambuco. Precisava concluir a repressão à Praieira, pois Pedro Ivo estava à solta, e Vicente de Paula ainda liderava a "gente da mata". Mas havia uma face senhorial da Praieira oposta ao "cavalcantismo", entre 1844 e 1848. Para essa facção da elite local - grandes proprietários rurais e deputados imperiais -, Honório trouxe a anistia, a paz. Não pretendia esmagar proprietários, bacharéis e ex-deputados. Por isso peitou os guabirus que, para Joaquim Nabuco, esperavam vingança e não a anistia. Questionado pelos guabirus, Honório disse ao Marquês do Recife (o tio da

\footnotetext{
${ }^{15}$ Falas do trono. São Paulo: Instituto Nacional do Livro-MEC/Melhoramentos, 1977, p. 171, 184. SISSON, Galeria, passim. NEEDELL, Jeffrey. The party of order, op. cit., nota 67, p. 348-349.

${ }^{16}$ QUINTAS, Amaro. O sentido social da Revoluçâo Praieira. Recife: Massangana, 1978, passim.

${ }^{17}$ Sobre Araújo Lima, veja-se: CADENA, Paulo Henrique Fontes. O vice-rei, op. cit., passim.

${ }^{18}$ NEEDELL, Jeffrey. The party of order, op.cit., p. 82-86. NABUCO, Joaquim. Um estadista do Império, op. cit., p. 58, 67. Sobre os saquaremas, veja-se: MATTOS. Ilmar Rohloff de. O tempo saquarema. São Paulo: Hucitec, 2005.
} 
esposa de Nabuco de Araújo) que não tinha ido a Pernambuco para ser levado pelo cabresto, confrontando assim tanto Araújo Lima como os Cavalcanti. ${ }^{19}$

Em editorial de 25 de abril de 1851, com o sugestivo título de "A Assembleia dos Guabirus em Oposição aos Saquaremas", o órgão dos remanescentes praieiros, O Liberal Pernambucano, ainda comentava essa moderação de Honório que anistiou mais do que perseguiu. Em 1856, a tensão com os guabirus chegaria ao ápice. Honório era presidente do gabinete. Ao discursar, foi apartado por Araújo Lima. Os anais do parlamento não revelam o que disse Araújo Lima. Os taquígrafos não ouviram, ou não anotaram. Não sabemos se fez referências ao desembarque de Sirinhaém. Mas a discussão era sobre as reformas eleitorais que haviam quebrado acordos antigos, tensionando a relação entre antigos aliados do partido conservador. O aparte, certamente, foi incisivo. Ao responder, colérico, Honório teve uma síncope, segundo alguns, ou um mal-estar, segundo outros. O fato é que faleceu em poucos dias. Dizem que, moribundo, delirando de febre, o Marquês do Paraná (Honório) balbuciava a resposta ao Marquês de Olinda (Araújo Lima). ${ }^{20}$ Pedro, então, chamou Caxias para presidir o gabinete. Araújo Lima, vencedor, logo voltaria ao ministério.

O longevo Araújo Lima enterraria muitos adversários. Ex-regente, áulico em dois reinados, líder de imensos apaniguados não obedecia a saquaremas ou Cavalcantis. Mas os irmãos Cavalcanti senadores, Holanda (Visconde de Albuquerque) e Francisco (Visconde de Suassuna) - um do "partido da ordem", o outro da "oposição parlamentar" - e o terceiro, Pedro (Visconde de Camaragibe), lider do clã na província, também não se deixavam "levar pelo cabestro". Como guabirus, eram quase sempre aliados, mas como ambicionavam tudo, eventualmente atuavam em campos opostos.

Postas essas nuances da relação entre Araújo Lima, os Cavalcanti e os saqueremas, fica mais fácil entender a carta do deputado imperial por Pernambuco, Pinto de Campos, a seu chefe político Cavalcanti, Pedro (Camaragibe), em junho de 1854, narrando uma audiência com Pedro II. Saiu convencido de que o presidente de Pernambuco não inspirava confiança, nem a Pedro II, nem a Araújo Lima e só não fora ainda exonerado porque estava difícil arrumar substituto. Ainda era 1854, o desembarque seria em outubro de 1855, o que mostra que, mesmo antes do episódio de Sirinhaém, José Bento já não satisfazia os arranjos políticos para Pernambuco. ${ }^{21} \mathrm{O}$ deputado Pinto de Campos continuaria escrevendo a Pedro, Visconde de Camaragibe, narrando os bastidores da política no parlamento e na corte imperial. Em maio de 1855, em outra carta, revelou que Araújo Lima “estava no maior encarniçamento" com

${ }^{19}$ NABUCO, Joaquim. Um estadista do Império, op. cit., p. 142. NEEDELL, Jeffrey. The party of order, op. cit., p. 163-164. MOSHER, Jeffrey. Political struggle..., op. cit., cap. 8.

${ }^{20}$ NEEDELL, Jeffrey. The party of order, op. cit., p. 197. ESTEFANES, Bruno Fabris. Conciliar o Império: Honório Hermeto Carneiro Leão, os partidos e a política de conciliação no Brasil monárquico (1842-1856). Dissertação (Mestrado em História Social) - Programa de Pós-Graduação em História Social, USP, São Paulo, 2010, p. 21-23. SISSON, S.A. Galeria, passim.

${ }^{21}$ Instituto Arqueológico, Histórico e Geográfico Pernambucano (IAHGP) - Fundo Visconde de Camaragibe (FVC) - Caixa 1. Joaquim Pinto de Campos ao Visconde de Camaragibe, Rio de Janeiro, 05/06/1854. 
Nabuco de Araújo, que, como vimos, era comensal dos Cavalcanti e não de Araújo Lima. Araújo Lima, então, teria dito que Nabuco de Araújo era “[...] um cancro que Pernambuco tem nutrido em seu seio e que quando houver qualquer vaga de Senador, não sendo ele o falecido, imediatamente se dirigirá para Pernambuco a guerrear de morte o mesmo Nabuco". ${ }^{22}$

O parlamento encerrou os trabalhos de 1855 no dia 4 de setembro ${ }^{23}$. O desembarque foi em outubro. As províncias estavam em ebulição, devido à divisão dos distritos eleitorais, os "círculos" propriamente ditos. O ministro da Justiça, Nabuco de Araújo, interferia no processo. Sempre ao lado dos Cavalcanti, perguntou a Pedro (Camaragibe), em novembro de 1855: "O que me diz, meu compadre, dos Círculos e como será melhor a divisão? Converse com o José Bento a quem escrevo sobre este respeito, e comunique-me o seu pensamento ${ }^{24}$."

O desembarque de 1855 pegou o Presidente José Bento no meio dessa campanha. Como a derrota praieira deixou a oposição aos guabirus muito fragilizada, o desembarque foi uma alento. O Liberal Pernambucano observou que, devido às eleiçóes e diante das denúncias na imprensa, ninguém queria se envolver, deixando o presidente isolado, sem defesa. Em tom de chacota, resumia a carreira de José Bento: "O seu primeiro conselheiro foi o Sr. Barão de Camaragibe [Pedro, irmão dos senadores Holanda e Antonio], e, para encher as fileiras, tratou de recrutar quanto bacharelzinho havia e que, tendo apenas saído da Faculdade, se julgava com direito à ocupar posiçôes de legisladores gerais e provinciais." ${ }^{25}$

Para os ingleses, como vimos, quem fez a apreensão foi o Coronel Drummond, e o desembarque só aconteceu porque o presidente José Bento deixou Sirinhaém sem autoridade em exercício ${ }^{26}$ e demorou a agir, possibilitando a fuga da tripulação e a escravização de dezenas de africanos. $\mathrm{O}$ desembarque só fracassou porque o comandante do navio foi parar no engenho errado. O certo, ali perto, pertencia a João Manoel de Barros Wanderley, sogro de Álvaro Barbalho Uchoa Cavalcanti. Para O Liberal Pernambucano, Sirinhaém era "um feudo" de Álvaro, ${ }^{27}$ que já fora deputado e comporia a bancada Cavalcanti no Senado, em 1871. Diziam a folha e o cônsul inglês que uns "cinquenta e tantos" cativos foram "subtraídos" por um irmão de Álvaro: Francisco Cavalcanti Wanderley, o "Chico Caçador. O Liberal Pernambucano noticiou ainda que nove africanos foram achados no engenho de João Manoel de Barros Wanderley, cujo irmão, o delegado de Sirinhaém, havia se licenciado de propósito. ${ }^{28}$ Vale informar que o padrinho de batismo de Araújo Lima, em 1794, foi Henrique Luis de

\footnotetext{
${ }^{22}$ IAHGP - FVC - Caixa 1. Joaquim Pinto de Campos ao Visconde de Camaragibe, Rio de Janeiro, 14/05/1855.

${ }^{23}$ HDBN - APB - Sessão de 1855 - Tomo Quarto. Rio de Janeiro: Typographia de Hyppolito José Pinto \& Ca, 1875, p. 342.

${ }^{24}$ IAHGP - FVC - Caixa 1. José Tomás Nabuco de Araújo ao Visconde de Camaragibe, 01/11/1855.

${ }^{25}$ HDBN. O Liberal Pernambucano, Recife, 12/03/1856.

${ }^{26}$ Sobre a "acefalia" da comarca em 1855, veja-se: VEIGA, Gláucio. O desembarque de Sirinhaém. In: Estudos, Recife: Editora Universitária, 1977, p. 53-62.

${ }^{27}$ HDBN. O Liberal Pernambucano, Recife, 18/06/1856.

${ }^{28}$ Ibidem, 17/12/1856.
} 
Barros Wanderley. Não sabemos o parentesco desse Barros Wanderley com o Coronel João Manoel Barros Wanderley, mas o Marquês de Olinda era afilhado de um Barros Wanderley, de Sirinhaém, onde também ficava o engenho da sua família, o Antas. ${ }^{29}$

Também se dizia que o responsável pelo embarque em Angola, João José de Farias, havia morado no engenho do Coronel João Manoel, reforçando as suspeitas do envolvimento dele e do genro, Álvaro Barbalho Uchoa Cavalcanti. ${ }^{30}$ Em suas cartas a seu chefe político, Pedro (Camaragibe), o deputado Pinto de Campos comentava a enrascada em que haviam se metido, admitindo que o sogro de Álvaro seria pronunciado no processo, ${ }^{31}$ e dizia, "[...] infelizmente um irmão de Álvaro está complicado até os olhos nesse contrabando". ${ }^{32}$

$\mathrm{Na}$ arena diplomática, farpas foram trocadas entre o Presidente José Bento e o Cônsul inglês em Pernambuco, Mr. Cowper. No parlamento, o Deputado Brandão disse que o depoimento de Cowper não era confiável, pois ele era amigo de Drummond, tanto que o visitou na prisão. ${ }^{33}$ De fato, eram próximos como mostrou um relatório de Cowper de 1843, publicado em 1854 no Daily News, no qual denunciou a brutalidade dos senhores de engenho pernambucanos. Um deles costumava mutilar seus cativos, castrava e enterrava gente viva. Outro cozinhou um cativo vivo e convidou os amigos para assistir. Entre os ingleses no Recife, havia um que, de tão cruel, levou um fujão a tentar se matar ao ser devolvido, de tanto medo que tinha dos castigos. ${ }^{34}$ Os engenhos de Drummond eram um pleasing contrast com os demais.

Quando esse relatório de 1843 veio a público no Daily News, em 1854, gerou um incidente diplomático. Interpelado pelo então Ministro dos Negócios Estrangeiros, Limpo de Abreu, José Bento contestou Cowper. Alegou que eram estórias mal contadas, pois uma acontecera no Pará, os dois proprietários brutais já haviam morrido e caberia ao cônsul procurar as autoridades na época, 1843. Limpo de Abreu aceitou a explicação e repassou à legação brasileira em Londres. ${ }^{35}$ Esse atrito entre José Bento e Cowper azedaria em 1855. Paranhos (futuro Rio Branco) interferiu em defesa do presidente. Em ácida correspondência com Jerningham, questionou porque os ingleses preferiam acreditar em um jornal da

${ }^{29}$ CASCUDO, Luis da Câmara. O Marquez de Olinda e seu tempo (1793-1870). São Paulo: Companhia Editora Nacional, 1938, p. 349.

${ }^{30}$ HDBN. O Liberal Pernambucano, Recife, 14/07/1856.

${ }^{31}$ IAHGP - FVC - Caixa 1. Joaquim Pinto de Campos ao Visconde de Camaragibe, Rio de Janeiro, 25/07/1856.

${ }^{32}$ IAHGP - FVC - Caixa 1. Joaquim Pinto de Campos ao Visconde de Camaragibe, Rio de Janeiro, 15/07/1856.

${ }^{33}$ HDBN. APB - Sessão de 11/07/1856, p. 145-146.

${ }^{34}$ Cowper to Aberdeen, 04/08/1843. In: Parliamentary papers slave trade, (PP-ST). [Class B and C], v. 26, p. 363-369.

${ }_{35}$ APEJE (Recife), Avisos Reservados, vol. 1, José Bento da Cunha Figueiredo a Limpo de Abreu, 25/01/1854, fls. 316-317; Legação imperial em Londres a Limpo de Abreu, 07/02/1854, fls. 376; Limpo de Abreu a José Bento da Cunha Figueiredo, 17/03/1854, fls. 373-375; Limpo de Abreu a José Bento da Cunha Figueiredo, 11/04/1854, fl. 347. 
oposição (O Liberal Pernambucano) do que em um governo que estancou o tráfico. ${ }^{36}$ Como acontecia antes de 1850, os ingleses acusaram o governo de conivência com o tráfico. Em carta a Clarendon, narrando o desembarque, Cowper disse que o pilot boat trouxera 250 pessoas. Trinta eram mulheres (women), o resto, meninos (boys). Para ele, era o primeiro de outros que viriam também carregados de crianças. ${ }^{37}$

Na Fala do Trono de 1856, Pedro II aludiu à tentativa de "alguns aventureiros" de reavivar o "abominável tráfico de escravos". ${ }^{38}$ Não se alongou, pois não cabia ao decoro régio defender autoridades provinciais. Isso era para o gabinete e sua base parlamentar. Os saquaremas juntaram-se aos guabirus para defender José Bento. Ferraz, outro egresso de Olinda, exigiu reação mais enérgica. Para ele, o governo respondeu aos ingleses como um súdito a um superior. ${ }^{39}$ Abrantes, por sua vez, apontou a necessidade de desfazer a opiniáo europeia de que o tráfico continuava, fomentada pelos ingleses depois de Sirinhaém e argumentou que o tráfico não acabou antes de 1850 por causa da opinião pública na época. ${ }^{40}$

Quem tomou as dores do clá Cavalcanti foi Holanda (já Visconde Albuquerque), que denunciou a " [...] autoridade conivente e protetora! Aí é que está o grande segredo do tráfico!"^1 Não precisava mencionar o nome do Coronel Drummond. Todos sabiam a quem se referia. Ao final, contestou as notas britânicas. Na mesma sessão, o líder saquerema Rodrigues Torres (Itaboraí) considerou injustas as alegaçôes dos ingleses. Asseverou que não foi por falta de força que o governo imperial não conteve o tráfico antes de 1850, mas, porque, na época, "o país não estava ainda inteiramente convencido da necessidade indispensável de acabar-se com o tráfico ${ }^{42}$."

Dantas, senador por Alagoas, reconheceu o exagero dos ingleses mas lembrou que eles haviam fornecido informaçôes que o governo ignorou: "Em nota de 20 de setembro, o governo inglês participou ao governo imperial que um tal Avellar se achava no rio Zaire da costa da África com dois palhabotes para conduzir africanos para o Brasil ou Cuba." Depois, em 12 de outubro, informaram que em Angra "tinha dado à costa uma embarcação que se dizia ter importado africanos". Em 22 de outubro, denunciaram: "ao norte do Espírito Santo, no Cabo de S. Tomé, dera à costa uma embarcaçấo que se dizia fora de africanos". Para o senador Dantas, não se justificava o governo querer informaçôes de todos, "menos dos ingleses". Ao mencionar as denúncias inglesas, Dantas tocou na ferida. O governo imputou o "extravio" de 60 africanos à negligência de Drummond, mas o senador de Alagoas achava

\footnotetext{
${ }^{36}$ Senhor Paranhos to Mr. Jerningham, 02/02/1856. In: PP-ST, [Class B], April 1, 1855 to March 31, 1856, Enclosure 1 in number 144, v. 42, p. 195-201.

${ }^{37}$ Cowper to Clarendon 03/11/1855. In: PP-ST, [Class B], April 1, 1855 to March 31, 1856, v. 42, p. 242-243.

${ }^{38}$ HDBN. APB - sessão de 1856 - Tomo primeiro. Rio de Janeiro: Typographia do Imperial Instituto Artístico, 1874 , p. 6.

${ }^{39}$ Annaes do Senado do Império do Brazil (ASIB) - anno de 1856 - livro 2, p. 177-181.

${ }^{40}$ ASIB - anno de 1856 - livro 1, p. 231-236.

${ }^{41}$ ASIB - anno de 1856 - livro 1, p. 331.

${ }^{42}$ ASIB - anno de 1856 - livro 1, p. 307.
} 
que o Coronel agira corretamente, apesar da fuga da tripulação e de que "alguns negros foram roubados". Apesar do ato falho, já que africanos livres não podiam ser "roubados" nem "extraviados", apenas reescravizados, Dantas mostrou que o governo fora avisado de um possível desembarque e que o apreensor do navio, Drummond, não era quem devia ser processado. $\mathrm{O}$ correto seria processar o presidente da província e seus aliados em Sirinhaém.

A defesa do presidente José Bento e dos guabirus envolvidos veio do topo, do presidente do gabinete, Honório, que, refutando as notas inglesas, indagou se o Brasil era algum tipo de protetorado britânico. Com ironia, perguntou a Dantas se havia examinado o processo propriamente dito. Dantas disse sim, mas que o delegado (Drummond) não fora pronunciado. Honório respondeu: "E não achou na província algum nome semelhante?” Era uma óbvia e sarcástica alusão ao filho do Coronel Drummond, Antonio, que compartilhava todos os sobrenomes do pai e foi acusado de ter se apropriado de vários cativos. Em resposta, Dantas disse: "O filho?... Senhores, estamos no tempo em que os pais respondem pelos crimes dos filhos e vice-versa." ${ }^{\prime 43}$

Honório admitiu que o capitão do navio procurou Drummond por engano. Mas não se justificava Drummond ter permitido sua fuga, alegando não ter "força de linha", já que estava em casa, com "muitos domésticos à sua disposição". Honório pontuou ainda a confusão de informações, pois, segundo disse, a primeira notícia falava em "150 e tantos escravos", depois "verificou-se que o patacho tinha saído com cerca de 200 e que morreram alguns na viagem, como tudo consta do processo". Em Sirinhaém, desapareceram "quarenta e tantos que provavelmente foram escolhidos a bordo, desembarcados e desencaminhados". Para Honório: "Houve pois negligência da autoridade e culpa no descaminho dos escravos que desapareceram, pelo que foram pronunciadas várias pessoas do lugar e entre elas um filho do Sr. Drummond". ${ }^{44}$ A defesa do Presidente da Província e seus aliados contava assim com o presidente do gabinete - o "rei Honório" no seu apogeu - que deixara de lado suas diferenças com os guabirus, os conservadores de Pernambuco, em favor de um bem maior: proteger o gabinete de ministros e o presidente da província das reverberaçóes do episódio.

Os ministros, todavia, sabiam de tudo, como mostra a carta "reservada" de Nabuco de Araújo ao novo presidente de Pernambuco, Sérgio Teixeira de Macedo (primo e colega de Eusébio em Olinda), substituto de José Bento, que se demitiu para não se "queimar" ainda mais no episódio, talvez forçado, como diziam seus adversários. Nabuco de Araújo queixou-se que o chefe de polícia pouco fez para pronunciar os Coronéis Drummond e João Manoel de Barros Wanderley, justificando sua inação porque os agricultores apoiavam o tráfico, o que o impedia de tomar medidas mais drásticas. Para Nabuco de Araújo, José Bento acatou esses argumentos e não agiu a contento, interrompendo as investigaçôes de janeiro a março

\footnotetext{
${ }^{43}$ ASIB - anno de 1856 - livro 1, p. 231-236 e 251-275.

${ }^{44}$ ASIB - anno de 1856 - livro 1, p. 273-274. 
de 1856. Nabuco de Araújo demitiu o chefe de polícia em abril de 1856 e sugeriu a Sérgio Teixeira de Macedo nomear o juiz Policarpo Lopes Leão para o posto. ${ }^{45}$

Era espinhosa a missão do novo presidente que veio da Inglaterra no mesmo vapor que o traficante Antonio Severino de Avellar, que os ingleses suspeitavam estar envolvido no desembarque de Sirinhaém. Avellar foi preso assim que pisou na corte. Sérgio Teixeira de Macedo desceu na escala do vapor no Recife e assumiu a presidência da província.

Era esse o cenário do topo do poder, mas foi nos engenhos que desapareceram os africanos. Não achamos o inventário do Coronel Drummond, mas há fontes sobre sua lida senhorial. Uma é o tal relatório de Cowper para Aberdeen, de 1843, que gerou um imbróglio diplomático ao ser publicado no Daily News, em 1853. Cowper considerava Drummond um dos homens mais interessantes e marcantes (most interesting and remarkable men) que conheceu em qualquer país (in any country). ${ }^{46}$ Há ainda o necrológio de Drummond, de 1866, escrito pelo General Abreu e Lima, um dos líderes da Praieira. ${ }^{47}$ Abreu e Lima datou sua amizade com Drummond no período joanino, na Academia Militar. Depois da execução do seu pai em 1817, o padre Roma, Abreu e Lima aventurou-se e terminou General de Bolívar. Já Drummond voltou ao Recife com Luís do Rego, governador depois de 1817. Era de família abastada e, se não fosse o episódio de Sirinhaém, passaria à história como irmão de Antonio Menezes de Vasconcellos Drummond, cujas "Anotaçôes" são uma fonte citadíssima na historiografia sobre a Independência. ${ }^{48}$

O Coronel Drummond envolveu-se em vários negócios, mas prosperou na agricultura. Era senhor de quatro engenhos. Durante a Praieira, disse Abreu e Lima, Drummond era delegado de Sirinhaém, tendo agido com moderação, não perseguindo ninguém e, quando foi pressionado, deixou o cargo. Vale lembrar que um dos combates da Praieira foi no engenho Camaragibe, em Sirinhaém. Na sua defesa, em 1855, Drummond alegou que deixou de ser delegado em 1849. A data confere com o que disse Abreu e Lima sobre sua moderação na Praieira, derrotada naquele ano. No mínimo, não apoiava os guabirus que queriam a tal vingança que Honório não deu quando presidiu Pernambuco.

Segundo Abreu e Lima e Cowper, os quatro engenhos de Drummond produziam 1.000 caixas de açúcar, além de mandioca, milho, etc., dispondo de uns 400 cativos e 50 trabalhadores livres. Ocupavam três léguas da praia e sete do interior, segundo Cowper. Ou seis léguas de praia, segundo Abreu e Lima. O Anjo e o Trapiche eram movidos a vapor. O Água Fria e o Jaciru à água. Os equipamentos para fabricar açúcar e aguardente eram ingleses.

\footnotetext{
${ }^{45}$ APEJE, Avisos Reservados vol. 1, fls. 491-496. José Thomaz Nabuco de Araújo a Sérgio Teixeira de Macedo, 11/05/1856.

${ }^{46}$ Cowper to Aberdeen, 04/08/1843, PPST, [Class B and C], v. 26, p. 363-369.

${ }^{47}$ Necrologia do Brigadeiro Gaspar de Menezes Vasconcellos de Drummond. In: HDBN, Diário de Pernambuco, 30/07/1866.

${ }^{48}$ Anotaçóes de Antônio Menezes de Vasconcellos Drummond a sua biografia publicada em 1836. In: Anais da Biblioteca Nacional, Rio de Janeiro, Biblioteca Nacional, v. 13, 1888.
} 
Com dois engenhos a vapor, em 1843, o Coronel estava à frente do seu tempo, pensava Cowper. Para Cowper e Abreu e Lima, o principal, todavia, era o modo como ele governava seus cativos. Drummond criara um sistema de recompensas, assim raramente alguém fugia a não ser quando cometia um crime. Para Abreu e Lima, ele administrava seus cativos como o "chefe de uma grande família", ao contrário de outros proprietários, como Antonio Francisco do Rego Barros, dono de um engenho próximo, um "horrible demon", que castigava cativos decepando membros, enterrando vivos, etc. Cowper viu algumas vítimas mutiladas. Rego Barros, que tinha o mesmo sobrenome do Barão da Boa Vista (Rego Barros), matou um Uchoa Cavalcanti (o sobrenome do Coronel Álvaro), o que mostra que a elite de Sirinhaém também brigava. Seu engenho foi atacado, devastado, e ele, morto. Segundo Cowper, naquele momento seus cativos deixaram-no sozinho, desamparado.

Para Cowper e Abreu e Lima, Drummond era o oposto disso. Em suas terras, empregava uma espécie de polícia e um código de regras baseado na "lei marcial" (martial law). Nem o feitor castigava sem consultar o Coronel, o juiz de tudo. Quando alguém era comprado ou chegava a idade de trabalhar, aprendia o tal código. Assim reinava a harmonia nos seus engenhos, onde todos eram tratados como "súditos", nas palavras de Abreu e Lima, e não como escravos. Drummond recompensava bons serviços, encorajava casamentos e punia o adultério. Cuidava pessoalmente da saúde de todos, sendo excelente médico (physician). Abreu e Lima disse que ele empregava um "cirurgião de partido" e formulava medicamentos em sua farmácia, confirmando Cowper.

Essa habilidade não impediu o cólera que grassava em 1855. Foi assunto dos relatórios de Cowper e serviu para evitar que alguém se aproximasse do navio negreiro, ancorado na ilha de Santo Aleixo, devido ao boato de que estava de quarentena, pois havia coléricos a bordo. Esse boato afastava curiosos. ${ }^{49} \mathrm{Na}$ carta reservada a Sérgio Teixeira de Macedo, Nabuco de Araújo reconheceu que o cólera serviu de pretexto para que as investigaçôes não avançassem..$^{50}$ Abreu e Lima contou que Drummond perdeu uns cem cativos na epidemia. Talvez seu filho tenha percebido no desembarque uma oportunidade de repor essas perdas. Dois meses depois do desembarque, Cowper disse a Clarendon que a epidemia tornava o tráfico uma grande tentação (great temptation). ${ }^{51}$ Para uma folha local, o cólera havia apressado a substituição dos cativos por braços livres. ${ }^{52}$

Apesar desses problemas, Cowper e Abreu e Lima consideravam Drummond um senhor exemplar. A senzala do engenho Trapiche era um perfeito retrato de conforto e limpeza

${ }^{49}$ O Liberal Pernambucano, Recife, 18/10/1855. Cowper to Clarendon, 21/10/1855. In: PPST, [Class B], April 1, 1855 to March 31, 1856, v. 42, p. 241.

${ }^{50}$ Arquivo Público Estadual Jordão Emerenciano, Recife (APEJE), Avisos Reservados, v. 1, Als. 491-496 verso: José Thomaz Nabuco de Araújo a Sérgio Teixeira de Macedo, 11/05/1856.

${ }^{51}$ Cowper to Clarendon, 19/12/1855. In: PPST, [Class B], April 1, 1855 to March 31, 1856 vol. 42, fl. 245.

${ }^{52}$ A Carteira, Recife, 24/03/1856. In: GONSALVES DE MELLO, José Antonio (org.). O Diário de Pernambuco e a história social do Nordeste. Recife: Gráfica Cruzeiro, 1975, v. 1, p. 3. 
(perfect picture of comfort and neatness). Apesar dos elogios, Cowper soltou que o trabalho começava ao amanhecer e ia até as 8 da noite: 14 horas de trabalho na entressafra, a época de relativo descanso (comparative rest) e 18 na safra. Abreu e Lima disse que quase ninguém fugia de seus engenhos. Mas o Coronel não se fiava nisso, pois fazia "duas revistas diárias". Mais adiante no relatório, Cowper condenou a jornada de 18 horas - a mesma dos cativos de Drummond, se bem que menor do que no engenho onde se mutilava e enterrava gente viva: 20 horas. Cowper notou que os domésticos eram mulheres, que não podiam passar da soleira da casa, ou seja, eram criadas recolhidas, como se dizia entáo, prisioneiras na casa grande. Lá trabalhavam 15 horas por dia fiando roupas para os cativos. ${ }^{53}$

Uma das principais observaçôes de Abreu e Lima foi sobre um "asilo para a infância desvalida" que havia em um dos engenhos de Drummond, provavelmente, o principal, o Trapiche, o mesmo onde foi parar o capitão do palhabote em 1855. Lá ele criava, e muito bem, segundo Abreu e Lima, mais de 50 crianças cativas, de dois a seis anos de idade. Havia, até, uma menina "quase branca", que ele libertou. Não sabemos se era a mesma menina mencionada por Cowper em duas cartas, mais de uma década antes: uma escravinha branca (little white slave girl), filha de uma cativa de Drummond com o seu maquinista inglês. Drummond alforriou a garota na frente de Cowper e mandou-a estudar no Recife às suas custas, deixando o pai muito feliz. ${ }^{54}$ Sobre a mãe cativa, Cowper e Abreu e Lima silenciaram. Mas Abreu e Lima não deixou de condenar no Necrológio os senhores de engenho que possuíam cativos mais "brancos" do que eles próprios. Abreu e Lima ressaltou, ainda, que o asilo era - literalmente - "um viveiro de bons escravos". Os meninos, portanto, saiam dali como modelos do bom escravo idealizado pela classe senhorial. Essa é uma observação particularmente importante, pois indica que o Coronel Drummond possuía um dos poucos criatórios de cativos devidamente documentados no Brasil.

É relevante ainda observar a localização das terras de Drummond, vizinhas de engenhos dos Cavalcanti, de Araújo Lima, dos Barros Wanderley, dos Accioli Lins e do Rego Barros, mutilador de gente. A praia não era o melhor porto natural da regiáo, mas Ponta de Serrambi atendia a cabotagem na foz do rio Sirinhaém, o caminho fluvial até os engenhos no interior. Em Pernambuco, náo havia praias oceânicas fora da zona de plantation. Todas as praias do litoral ficavam nos limites de engenhos ou em frente a povoaçôes controladas por senhores de engenho, ungidos juízes de paz, delegados, subdelegados e oficiais da guarda nacional. A repressão dependia deles. A conivência também. ${ }^{55}$ Não havia onde atracar um

\footnotetext{
${ }^{53}$ Cowper to Aberdeen, 04/08/1843. In: PP, Correspondence with Foreign Powers, relative to the slave trade [Class B and C], 1844, v. 26, n. 307, p. 363-369.

${ }^{4}$ Cowper retomou esse assunto em 1844. Cowper to Aberdeen, 01/01/1844. In: PPST, [class B and C], v. 28, p. 409.

${ }^{55}$ Sobre esses desembarques, veja-se: CARVALHO, Marcus J. M. O desembarque nas praias: o funcionamento do tráfico de escravos depois de 1831. Revista de História, São Paulo, n. 167, p. 230-232, 2012.
} 
negreiro sem que algum proprietário rural o acolhesse - ou recusasse - como Drummond alegava ter feito.

O problema é que o comandante do navio foi parar no engenho errado. Nisso todos concordavam. A controvérsia girava em torno da culpa de Drummond e seu filho Antonio, ou da conivência das autoridades guabirus com o Coronel João Manoel de Barros Wanderley, o consignatário do barco, e dois outros proprietários cúmplices. ${ }^{56} \mathrm{Um}$ deles era "Chico Caçador”, irmão do Coronel Álvaro Barbalho Uchoa Cavalcanti, como vimos, futuro senador e genro do próprio João Manoel, o consignatário do negreiro. O Liberal Pernambucano publicou a sentença da auditória de marinha. Em sua defesa, Chico Caçador alegou que, na ocasião, estava no engenho das Coelhas, a duas léguas de distância. O outro senhor de engenho acusado de ficar com os africanos, José Francisco de Accioli Lins, conhecido por Cazumba, disse que estava no engenho Sibiró, também distante do local do desembarque. A denúncia, todavia, derrubava o argumento da distância, pois os africanos "subtraídos" foram de barco para Ponta de Serrambi, o porto de cabotagem que mencionamos. ${ }^{57}$

Não era a primeira vez que um navio negreiro aportava em local fora do controle do seu consignatário. Nesses casos, eram necessárias propinas para que a carga humana não fosse "roubada" por senhores de engenho que comandavam a polícia e a justiça local. Esses roubos foram objeto de crônica do "padre Carapuceiro", o irmão do outro Lopes Gama, ministro em gabinetes de Araújo Lima que, como vimos, o indicou senador pelo Rio de Janeiro, atropelando o candidato saquarema. ${ }^{58} \mathrm{O}$ problema aumentou quando a classe senhorial dividiu-se entre praieiros e guabirus. Em 1845, a polícia praieira começou a atacar os desembarques consignados a seus adversários. Os "africanos livres", porém, desapareciam. Ficavam com os próprios apreensores, segundo os relatos da diplomacia e marinha inglesas. ${ }^{59}$ Para Cowper, o tráfico provincial entrou em declínio devido à conivência do governo praieiro com essas práticas. Os principais traficantes da província atribuíam declínio do tráfico ao partido no poder, os praieiros. ${ }^{60}$

A ação da polícia durante o governo praieiro (1845-48) não ficou sem reação. A oportunidade veio na apreensão do Bom Jesus dos Navegantes, em 1846, cuja carga humana desapareceu. Só que, dessa vez, um primo do Chefe de Polícia praieiro foi flagrado com

\footnotetext{
${ }^{56}$ Cowper to Clarendon, 19/12/1855. In: PPST, [Class B], April 1, 1855 to March 31, 1856, v. 42, p. 245.

${ }^{57}$ Arquivo Nacional, Rio de Janeiro (ANRJ), Justiça, IJ6 - 521: O Liberal Pernambucano, Recife, 27/06/1856. Em 1857, essa folha transcreveu peças do processo, inclusive provas testemunhais e cartas sobre Avellar. Veja-se: HDBN, O Liberal Pernambucano, Recife, 20/02/1857, 21/02/1857, 22/02/1857, 24/02/1857, 25/02/1857, 26/02/1857, 27/02/1857, 28/02/1857, 02/03/1857.

${ }^{58} \mathrm{HDBN}$, O Carapuceiro, Recife, 23/03/1839.

${ }^{59}$ Commander Montgomery to Rear Admiral Inglefield, 04/05/1846, Enclosure 2 in number 12. In: PPST, [Class A], v. 32, p. 46. Veja-se também: Cowper to Aberdeen, 01/04/1846, PPST, [Class B, C and D], v. 33, p. 294.

${ }^{60}$ Cowper to Palmerston, 12/02/1847. In: PPST, [Class B and C], vol. 26, p 299. "The reason of the cessation of the slave trade is greatly owing to the continuance of the Praieiro or Democratic party in power". Cowper to Palmerston, 19/02/1848. In: PPST, [Class B and C], v. 26, p. 135.
} 
africanos boçais. Os guabirus usaram o episódio na eleição para senador contra o candidato praieiro. Ambos os partidos passaram a se acusar mutuamente de conivência com o tráfico. Mais um jogo de espelhos onde todos viam-se refletidos. A principal defesa guabiru veio de Nabuco de Araújo, em livreto anônimo, cuja autoria foi reconhecida postumamente por seu filho, Joaquim Nabuco. ${ }^{61} \mathrm{O}$ futuro ministro da Justiça atacou os praieiros, mas admitiu que os Cavalcanti e toda a elite provincial, de uma maneira ou outra, participavam do tráfico. ${ }^{62}$

Como as autoridades locais podiam se apropriar de cativos desembarcados nas praias sob seu controle, e o palhabote foi parar no engenho errado, não seria estranho se o filho de Drummond tivesse ficado com uma parte da carga como propina. Drummond defendeu seu filho, alegando que os africanos ficaram com o consignatário do barco, o Coronel João Manoel. Da perspectiva da História do tráfico, o mais importante não é saber quem tinha razão nessa controvérsia, mas perceber que, sem o apoio dos senhores de engenho, os desembarques não eram seguros. Os proprietários do litoral eram delegados, juízes, coronéis e eram partes interessadas. $\mathrm{O}$ tráfico dependia deles. Todos sabiam disso.

Quanto ao Coronel João Manoel e seu genro, o futuro senador Álvaro, sabemos que já participavam do tráfico antes de 1855 . Como a elite senhorial sabia resguardar seus nomes de atividades infamantes, conhecemos apenas uma fração de seus crimes. Mesmo assim, em 1846, o Diário Novo já denunciava o tráfico em Sirinhaém quando Álvaro Barbalho Uchoa Cavalcanti ocupava a prefeitura da comarca, tendo como subdelegado em Sirinhaém João Manoel de Barros Wanderley. ${ }^{63}$ Os mesmos genro e sogro, portanto, do desembarque de 1855.

Não foi esse o único caso protagonizado pelo Coronel João Manoel. Logo depois de 1850, o tráfico deu um salto em Pernambuco, como mostrou Peter Eisenberg, principalmente por causa da maior vigilância no sudeste. $\mathrm{O}$ cônsul inglês em exercício, $\mathrm{Mr}$. Christophers, confidenciou a Palmerston que os feudal magnates da província estavam ativos no tráfico. De novembro de 1850 a janeiro de 1851, houve três desembarques feitos pelo conhecido traficante Magalhães Bastos e o senhor de engenho "Barros Wanderley". Embora o presidente da província na época quisesse coibir o tráfico, disse Mr. Christophers, a polícia fora incapaz de proceder contra os suspeitos, apreendendo poucos africanos entre centenas desembarcados. Na província vizinha, Alagoas, haviam entrado uns mil cativos. Seu presidente era José Bento, que presidiria Pernambuco em 1855. ${ }^{64}$

\footnotetext{
${ }^{61}$ NABUCO, Joaquim. Um estadista do Império, op. cit., p. 36.

${ }^{62}$ IAHGP. Justa apreciação do predomínio praieiro ou história da dominação da praia. (Recife, 1847), Recife, Secretaria de Educação e Cultura, 1977, passim.

${ }^{63}$ HDBN. Diário Novo, Recife, 31/01/1846.

${ }^{64}$ Acting Council Christophers to Palmerston, 12/02/1851. In: British and foreign State papers, 1850-1851, v. XL, p. 436-439.
} 
Duas folhas também citaram o Coronel João Manoel como responsável, ao menos, por um "desembarque de africanos boçaes" em Ponta de Serrambi, na foz do rio Sirinhaém. Mais de cem homens varejaram seu engenho e encontraram provas, inclusive seis africanos boçais, mas ninguém foi incriminado. ${ }^{65}$ Lamentando a ineficiência policial, Mr. Christophers relembrou saudoso, "quatro anos atrás", quando os praieiros, o partido apoiado pelo povo (backned by the people) conseguiu estancar o tráfico. Christophers mencionou o caso do Bom Jesus, em 1846, quando o Chefe de Polícia praieiro demitiu do posto de delegado o próprio primo, a very influential planter, indiciado no caso. "Agora" (1851), o "feudal party" estava de volta ao poder e o tráfico também. ${ }^{66}$

Uma segunda questáo levantada nessa controvérsia era quem teria mandado o carregamento de Angola. Havia duas possibilidades. A primeira, como vimos, seria o renomado traficante Antonio Severino Avellar. Os ingleses avisaram que ele preparava navios negreiros em Angola para desembarcá-los em algum ponto entre Campos (RJ) e a Bahia. O governo brasileiro alegou que as denúncias eram antigas e os desembarques seriam no sudeste. Não havia por que esperá-los em Sirinhaém. A segunda possibilidade é que a conexão em Angola era João José de Farias, o tal sujeito que, antes de ir para Angola, havia morado em um engenho do Coronel João Manoel.

Em público, os defensores do governo alegavam que o "mulato Farias", nas palavras de Paranhos, residia em Angola e não em Pernambuco. Assim, os culpados pelo desaparecimento dos africanos eram o inepto Drummond e seu filho oportunista. ${ }^{67}$ Mas Nabuco de Araújo sabia quem era Farias. Na sua correspondência reservada a Sérgio Teixeira de Macedo (o substituto de José Bento na presidência de Pernambuco), admitiu que Farias mandou os cativos de Angola e asseverou que ele "foi da casa de João Manoel e com ele muito relacionado" ${ }^{68}$ Da perspectiva da História do tráfico, essas duas possibilidades confirmam as extensas conexóes dos grandes senhores de engenho com o tráfico.

Farias, o antigo morador do engenho Serraria do Coronel João Manoel, não foi preso pois estava em Angola, mas Antonio Severino de Avellar foi, assim que chegou ao Rio de Janeiro, vindo de Portugal em um vapor inglês, que fez escala no Recife. O mesmo navio, como vimos, trazia Sérgio Teixeira de Macedo, que deixou a representação brasileira em Londres para assumir a presidência de Pernambuco. Sérgio Teixeira de Macedo vinha de uma família de negociantes atlânticos de cativos que operava a partir do Rio de Janeiro. ${ }^{69}$

${ }^{65}$ IAHGP, A Imprensa, Recife, 17/12/1850. Agradecemos a Bruno Câmara por esta informação. HDBN, Echo Pernambucano, Recife, 21/01/1851, 25/04/1851.

${ }^{66}$ Acting Council Christophers to Palmerston, 12/02/1851. In: British and foreign State papers, 1850-1851, v. XL, p. 437-438.

${ }^{67}$ HDBN. O Liberal Pernambucano, Recife, 14/07/1856. Senhor Paranhos to Mr. Jerningham, 02/02/1856. In: PPST, [Class B], April 1, 1855 to March 31, 1856, Enclosure 1 in number 144, v. 42 p. 198.

${ }^{68}$ APEJE, Avisos Reservados, v. 1, fls. 491-496 verso, José Thomaz Nabuco de Araújo a Sérgio Teixeira de Macedo, 11/05/1856.

${ }^{69}$ NEEDELL, Jeffrey. The party of order, op. cit., p. 28, 330. 
Tanto ele como Avellar, portanto, conheciam bem o caso. O presidente desceu no Recife. Avellar prosseguiu até o Rio de Janeiro, onde foi detido, interrogado pelo chefe de polícia da corte e reenviado a Pernambuco para ser julgado pela Auditoria de Marinha. ${ }^{70}$

Avellar disse no interrogatório que residia em Niterói, mas tinha propriedades em Açores e Lisboa e conexōes em Londres, Liverpool, Southampton, Nova York, Cuba e, é claro, na África. Como observou Roquinaldo Ferreira, estava bastante à vontade no interrogatório, pois não relatou nada que o comprometesse e, quando falou do tráfico, falou de Cuba, ou de antes de 1850, quando era tolerado. ${ }^{71}$ Aos 46 anos, era rico, vivia de rendas mas começou de baixo na "vida marítima". Tornou-se comerciante, foi residir em Angola, onde negociou com goma, cera, azeite e, obviamente, escravos, admitiu. Major nas milícias em Angola, disse que recebeu o hábito da Ordem da Conceiçấo. Circulava sempre, ou quase sempre, em vapores ingleses. Admitiu, ainda, que morou alternadamente em Angola e Rio de Janeiro, entre 1844 e 1850, o auge do tráfico na corte, como observou Ferreira. ${ }^{72}$

A partir de 1851, fez várias viagens, com longas estadias em Lisboa, Rio de Janeiro, Londres, Açores e Nova York. Em Cuba, todavia, só pôde ficar 12 dias, por pressão do cônsul inglês, que o acusava de traficante. Avellar rechaçou a acusação, alegando que não gozava da "afeiçáo" do governo inglês porque movera um processo por "estragos feitos pelo cruzeiro inglês em uma feitoria da pertença dele respondente no porto de Ambriz". Admitia assim que era dono de uma feitoria do tráfico, mas negava ser traficante.

De Cuba, seguiu para Nova York, onde morou vários meses. Esteve em Montreal e viveu longas temporadas em Charleston e Nova Orleans. Da América foi para Liverpoool, em junho de 1855, como sempre em um vapor inglês. Ficou até setembro, depois seguiu para Paris. Os ofícios do governo que acompanham seu depoimento indagavam se estivera em Liverpool em busca de "fazendas para a costa da África". Indagavam ainda se ele havia visitado a "exposição de Paris", ou seja, a Exposicion Universelle de 1855. De Paris, Avellar passou pela Itália, depois foi a Lisboa, de onde voltou ao Rio de Janeiro, como vimos, no mesmo vapor que o ex-diplomata na Inglaterra, Sérgio Teixeira de Macedo, primo e colega de Faculdade de Eusébio e advindo de uma família de traficantes, que vinha substituir o presidente José Bento, politicamente afogado no imbróglio de Sirinhaém. Avellar fez questão de mencionar seu companheiro de viagem. Não sabemos se conversaram, mas, certamente, a Exposição de Paris teria sido um excelente tema de prosa.

Mesmo alegando inocência, Avellar contou que viu o barco capturado no porto do Recife e, com o seu "conhecimento" do assunto, fez um "exame no dito palhabote" e disse: "não duvida asseverar que foi construído no rio Zaire, suspeitando que a especulaçáo seja

\footnotetext{
${ }^{70}$ ANRJ, Justiça, IJ6 522, Pasta “Tráfico, Antonio Severino de Avellar, 1852-1863”, "Interrogatório feito ao indiciado em crime Antonio Severino de Avellar", 16/11/1856.

${ }^{71}$ FERREIRA, Roquinaldo Amaral. Dos sertôes ao Atlântico: tráfico ilegal de escravos e comércio lícito em Angola, 1830-1860. Dissertação de Mestrado, UFRJ, Rio de Janeiro, 1996, p. 98 e passim.

${ }^{72}$ FERREIRA, Roquinaldo Amaral. Dos sertôes ao Atlântico..., op. cit. p. 98.
} 
de alguns caixeiros das antigas feitorias de escravos que ainda permanecem ali em diversas negociaçóes." Perguntado sobre quem eram, prontamente entregou os nomes de traficantes bem conhecidos, provavelmente adversários ou concorrentes. ${ }^{73}$

Para o caso de Sirinhaém, é relevante o que disse sobre o negreiro Nova Tentativa. Ao ser indagado sobre aquela embarcação, Avellar negou qualquer envolvimento naquele ano, 1856. Todavia, admitiu que conheceu o barco em 1853, quando era "seu capitão o piloto Mesquita". Em 1853, a Nova Tentativa esteve em Lisboa, Rio de Janeiro, Londres e Faial. Passou ainda pela ilha Terceira onde deixou os filhos do cônsul inglês. Além do sarcasmo, ao falar que os filhos de um cônsul inglês viajaram em um navio negreiro, Avellar deixou ali uma informação relevante. O nome do piloto da Nova Tentativa, em 1853, era "Mesquita". Seria esse Mesquita o atrapalhado comandante do palhabote de Sirinhaém, Augusto Cezar de Mesquita?

Não é essa a única menção ao nome Mesquista como comandante de navio negreiro. Avellar trazia consigo várias cartas que também foram apreendidas. Delas, resta-nos uma circunstanciada lista para uso do ministro Nabuco de Araújo. Além dos nomes de remetentes e destinatários, a lista resume o conteúdo das missivas, com passagens aspeadas, copiadas dos originais. Apesar de nomes cifrados, para náo comprometer os traficantes, essa fonte complementa o depoimento, como observou Roquinaldo Ferreira, inclusive sobre o caso de Sirinhaém.

Em uma dessas cartas, Mesquita aparece duas vezes, mas sem prenomes. A carta dizia que Mesquita, "Teixeira e Machado" viajaram na Progressista. Mais adiante, menciona um desentendimento com Machado por causa de dinheiro entregue a Mesquita. Não há detalhes dessa altercação, mas Machado "zangou-se" na confusão. Infelizmente, o nome completo do ex-piloto do Nova Tentativa, o "Mesquita", não aparece nem no depoimento de Avellar, nem nas cartas. Mas não é impossível que fosse Augusto Cezar de Mesquita, que foi parar no engenho errado em Sirinhaém e depois fugiu.

Vale ainda ressaltar a desenvoltura de Avellar entre os ingleses, cujo país tanto visitara e, em cujos vapores, viajava. O seu sócio em Nova York, Gaspar Joaquim da Motta, tinha um correspondente em Londres: Knowles \& Foster. Mr. Cowper disse, em 1843, que havia ingleses bem adaptados à sordidez escravista, tanto que um cativo fujão cortou a própria garganta "from ear to ear" ao ser devolvido pela polícia a seu senhor inglês no Recife. Não é irrelevante, portanto, observar que a ilha de Santo Aleixo, onde o negreiro ancorou em 1855, pertencia a um negociante inglês da praça do Recife, John Donneley. A ilha já servira ao tráfico antes. Está na carta do conhecido traficante Azevedinho, instruindo o mestre do Camóes, capturado pelos ingleses em 1837. O local previamente combinado para o desembarque não consta da carta. No entanto, alertou Azevedinho, o mestre devia ficar atento, pois, talvez, tivesse que desembarcar em Sirinhaém (como em 1855). Nesse caso, o mestre do Camóes poderia esperar "ao abrigo da ilha de Santo Aleixo que me dizem oferece até bom

\footnotetext{
${ }^{73}$ Veja-se ibidem, p. 100 e passim.
} 
ancoradouro." ${ }^{74}$ Ora, se os brasileiros eram coniventes, a diplomacia inglesa era, no mínimo, incompetente, pois a ilha, que pertencia a John Donneley em 1855, servia ao tráfico ao menos desde 1837, segundo uma carta apreendida pelos próprios ingleses.

Também vale notar as referências de Avellar à conhecida "companhia portuguesa", que operava a partir de Nova York abastecendo o mundo atlântico de cativos. ${ }^{75}$ É bem sabido que, depois de 1831, muitos negreiros eram adquiridos nos Estados Unidos, cuja bandeira servia de proteção contra a marinha inglesa. ${ }^{76}$ Talvez esteja aí uma das pontas perdidas do nexo entre traficantes de Pernambuco e estadunidenses, revelada no caso do vapor Cacique, comprado em Nova York, em 1845, pelo negociante estabelecido no Recife, José Antonio de Seixas. Ao chegar no Recife, instalaram um canhão e trocaram a hélice do motor de popa por roda de pás lateral. Isso diminuia a velocidade, mas permitia remover o motor e a caldeira para o convés, liberando o poráo para os cativos, explicou a marinha inglesa. ${ }^{77}$ Essa adaptação foi feita na Fundição da rua da Aurora, de Mr. Starr, o inglês que mais escravos possuía no Recife, segundo Cowper: 28 na fundição e 3 em casa. ${ }^{78} \mathrm{O}$ dono da Cacique conseguiu disfarçar sua finalidade, mas um marinheiro inglês contou a Cowper que o navio ia para a África. O mesmo revelou um tripulante americano ao cônsul do seu país no Recife. Os papéis do navio indicavam Santos como destino com escala no Rio de Janeiro. ${ }^{79}$

Ao chegar em Cabinda só havia 1.000 cativos nos barracôes. O capitáo preferiu esperar ao largo até completar a carga de 1.500. Avistada, a Cacique foi perseguida e capturada a 140 milhas da costa. Além de 24 portugueses e um brasileiro, havia 4 americanos cuidando dos motores. Segundo o Comodoro Jones, trabalharam duro nas caldeiras tentando escapar e quase conseguiram. Mesmo sem cativos, o vapor foi condenado pela cláusula de equipamentos. ${ }^{80}$ Os proprietários protestaram: seria loucura arriscar um barco de duzentos contos de réis numa aventura dessas. Apareceu, então, a verdadeira dona do vapor, a angolana Anna Joaquina do Nascimento, viúva do comendador Antonio Ferreira do Nascimento. Seixas, seu

\footnotetext{
${ }^{74}$ National Archives (Londres): Foreign Office, 315/69, José Francisco de Azevedo Lisboa a Antonio Gomes da Silva, 20/02/1837.

${ }^{75}$ FERREIRA, Roquinaldo Amaral. Dos sertóes ao Atlântico, op. cit., p. 97.

${ }^{76}$ GRADEN, Dale T. O envolvimento dos Estados Unidos no comércio transatlântico de escravos para o Brasil, 1840-1858. Afro-Ásia, Salvador: CEAL/UFBA, v. 35, 2007, passim. HORNE, Geraldo. O Sul mais distante: os Estados Unidos e o tráfico de escravos africanos. São Paulo: Companhia das Letras, 2010, cap. 2, passim.

${ }_{77}$ Commodore Jones to Commodore Skinner, 15/11/1845. PPST, [Class B, C e D], Session 19 January-23 July 1847. Enclosure 12. In: n. 172, v. 33, fl. 289.

${ }^{78}$ Commodore Jones to the secretary to the Admiralty, 08/11/1845. PPST, [Class B, C e D], Session 19 January-23 July 1847, v. 33, fls. 287-288. José Antonio Gonsalves de, Inglêses em Pernambuco, Recife, IAHGPE, 1972, p. 52-53, 58-59.

${ }^{79}$ Cowper to Aberdeen, 16/05/1846 e Cowper to Mr. Hamilton, 07/08/1846, PPST, [Class B, C e D], Session 19 January-23 July 1847. Enclosure 12. In: n. 172, v. 33, fl. 296-297.

${ }^{80}$ Aberdeen to Cowper, 21/02/1846 e Enclosures 1 a 12. In: PPST, [Class B, C e D], Session 19 January-23 July 1847, vol. 33, p. 283-290. Edmund Gabriel to Lord Aberdeen, 31/12/1845. In: PPST, [Class A], vol. 32, p. 293.
} 
procurador, adquiriu o barco da firma J. Gardner, em Nova York, por 50 mil dólares. Quase metade foi adiantada, o resto seria saldado depois, ficando o próprio vapor como garantia. ${ }^{81}$

Apesar do fracasso logo na primeira viagem, a marinha inglesa preocupou-se. Escrevendo para o Comodoro Skinner, o Comodoro Jones disse que esse era o primeiro vapor a ser usado no tráfico. Era grave, pois, embora vagarosos, navegavam em qualquer direção, até contra os ventos. ${ }^{82}$ Devido ao fiasco, a Cacique praticamente inexiste para a História do tráfico. Mas foi a partir de Pernambuco que, pela primeira vez, um vapor foi usado no tráfico. A rota para Pernambuco era secundária, porém curta e menos vigiada. ${ }^{83}$ Talvez essa conexão entre Pernambuco e Nova York jamais chegue à tona, mas existiu e talvez Avellar fizesse parte dela.

As malhas do tráfico envolviam gente ardilosa, capaz de esconder seus crimes. Mas é possível perceber padróes que mostram que a principal excepcionalidade do caso de Sirinhaém foi o ano, 1855, e a incompetência do capitão Mesquita que foi bater na porta errada. Era um pequeno navio abarrotado de crianças ${ }^{84}$ consignado a proprietários rurais vinculados à elite imperial por laços políticos e familiares. É impossível comprovar todas as suspeitas aludidas no caso, mas podemos perceber as imagens nesse jogo de espelhos, onde todos se viam refletidos, pois, no debate, há muitas concordâncias. Mesmo que todos mentissem (e como!) também falavam de possibilidades concretas, o que permite a construção de uma narrativa razoavelmente coerente do episódio.

Assim, o consignatário da carga não era Drummond, mas o Coronel João Manoel, ligado aos Cavalcanti, à presidência da província e ao ministro da Justiça. Alguns dos cativos ficaram com Chico Caçador, irmáo do futuro senador pelo clá Cavalcanti, o Coronel Álvaro, genro do consignatário do barco e primo dos irmãos Cavalcanti senadores: Holanda, Francisco e Pedro. Mas também não é absurdo supor que o filho de Drummond possa ter aproveitado a oportunidade para apropriar-se de alguns cativos, "escolhidos", como diziam seus adversários. Apesar da dificuldade de identificar exatamente quem se apropriou daqueles "africanos livres", para a História do tráfico, o principal é perceber que os proprietários locais foram protagonistas e que o tráfico ramificava-se na política provincial e imperial, chegando muito perto do gabinete ministerial.

\footnotetext{
${ }^{81}$ Arquivo Histórico do Itamaraty (Rio de Janeiro), Escuna Cacique: Exposição do Direito a Idemnização pelo apresamento do Vapor Brasileiro Cacique, 23/02/1860. Contrato que fazem os abaixo assinados Jose Antonio de Seixas e Antonio Ferreira do Nascimento, de um lado, e o Sr. J. Gardner, [...] de outubro de 1844. ${ }^{82}$ Commodore Jones to Commodore Skinner, 15/11/1845. PPST, [Class B, C e D], Session 19 January-23 July 1847, Enclosure 12. In: number 172, v. 33, fl. 289.

${ }^{83}$ Sobre a demografia do tráfico para Pernambuco, veja-se: DOMINGUES DA SILVA, Daniel e ELTIS, David. The slave trade to Pernambuco, 1561-1851. In: ELTIS, David e RICHARDSON, David (eds.). Extending the frontiers: essays on the New Transatlantic Slave Trade Database. New Haven: Yale University Press, 2008. p. 95-129. COSTA, Valéria Gomes. O Recife nas rotas do Atlântico negro: tráfico, escravidão e identidades no oitocentos. Revista de História Comparada, Rio de Janeiro v. 7, 1, p. 186-217, 2013.

${ }^{84}$ Sobre as crianças traficadas, veja-se: VALENCIA VILLA, Carlos e FLORENTINO, Manolo. Abolicionismo inglês e tráfico de crianças escravizadas para o Brasil, 1810-1850. História, São Paulo, v. 37, p. 1-20, 2016.
} 
No final, foram detidos um Cavalcanti Wanderley (o "Chico Caçador"), José Francisco de Accioli Lins (o "Cazumba") e o filho de Drummond. Sofreram, mas certamente menos do que a gente miúda também pronunciada, como o barqueiro Manoel Elias Salgado, o pescador Manoel Fidelis do Nascimento e Antonio da Silva Pereira, morador de engenho. Aliás, foi o pescador quem provocou a confusão, pois, quando o capitão Mesquita ouviu de Drummond que estava no engenho errado, ele apontou o dedo para o pescador e disse que tinha sido ele que o levou até lá. ${ }^{85}$ Muita gente deve ter ficado com raiva do pobre do Manoel Fidelis, pois bastaria ter levado Mesquita para o engenho certo que o desembarque teria sido bem sucedido e esse artigo nem teria sido escrito.

A sentença da Auditoria de Marinha absolveu o filho de Drummond e o pescador que levou Mesquita para o engenho errado. Mas o caso de Sirinhaém ficaria marcado na vida do filho de Drummond. Ao tentar uma vaga de professor da Faculdade de Direito, entre 1861 e 1862, Pedro II relembrou o episódio com reserva, mas terminou nomeando. ${ }^{86}$ Já Chico Caçador, Cazumba e o morador de engenho que os ajudou a subtrair 46 africanos foram condenados a seis anos de prisão e multa de 200 mil réis por africano apreendido. A sentença concluiu que o filho de Drummond "não tinha relação" com Wanderley, o Chico Caçador, e tinha "indisposição" com Acioli Lins, o Cazumba. Era a redenção da oposição aos guabirus, pois quem julgou o processo foi Polycarpo Lopes de Leão, o Auditor da Marinha e Chefe de Polícia, indicado pelo próprio Nabuco de Araújo.

Os condenados apelaram à Relação de Pernambuco, onde rapidamente foram todos absolvidos por falta de provas. A nobreza togada cumpria assim o seu papel de cúmplice nos desmandos da nobreza da terra. A oposição continuou a fustigar o governo, acusando José Bento de não ter colhido provas para beneficiar Álvaro Barbalho Uchoa Cavalcanti, que queria salvar o irmão e o sogro, ou seja, Chico Caçador e o Coronel João Manoel. ${ }^{87} \mathrm{~A}$ absolvição geral também não agradou Nabuco de Araújo, pois desmoralizava o governo imperial perante os ingleses. Decidiu, então, dar o que chamou de "golpe de estado" no tribunal: aposentou dois desembargadores e afastou um outro. Os Cavalcanti protestaram, mas se calaram quando o ministro afirmou que um dos desembargadores, o Valle, era um "notório mercador de sentenças". A absolvição, portanto, não foi gratuita, envolveu uma propina, como era comum no tráfico. ${ }^{88}$

A historiografia sobre o Brasil imperial foi muito influenciada pelo filho de Nabuco de Araújo, pois poucos livros são tão citados como Um estadista do Império, no qual Joaquim Nabuco escreveu um subcapítulo para defender ardorosamente as atitudes do seu pai no episódio de Sirinhaém, mesmo reconhecendo a óbvia participação da fina flor da oligarquia terratenente

\footnotetext{
${ }^{85}$ ANRJ, Justiça, IJ6 - 521, O Liberal Pernambucano, Recife, 27/06/1856.

${ }^{86}$ VEIGA, Gláucio. O desembarque de Sirinhaém, op. cit., p. 42-43.

${ }^{87}$ HDBN. O Liberal Pernambucano, Recife, 17/12/1856.

${ }^{88}$ IAHGP - FVC - Caixa 1. José Tomás Nabuco de Araújo ao Visconde de Camaragibe, Rio de Janeiro, 01/12/ 1856.
} 
e da elite imperial no tráfico como um todo. Para Joaquim Nabuco, Nabuco de Araújo, seu pai, considerava a repressão ao tráfico não apenas "uma responsabilidade, mas uma glória" ${ }^{89}$ Joaquim Nabuco procurou, portanto, diminuir a relevância desse episódio, pois ele revelava o vínculo do seu pai com o tráfico. O desembarque de Sirinhaém ficou, então, praticamente esquecido pela historiografia. Na contemporaneidade, todavia, dispomos de uma diversidade de fontes trabalhadas neste texto que servem de contraponto aos escritos de Joaquim Nabuco, sempre cioso da suposta imparcialidade e justeza do seu pai, Nabuco de Araújo, um político astuto que, aos poucos, saía da sombra dos Cavalcanti para se abrigar debaixo de outras asas mais largas, as do imperador, no gabinete da conciliação.

A influência historiográfica dessa obra de Joaquim Nabuco reforçou a defesa do presidente José Bento, do Coronel João Manoel e dos guabirus, deixando a argumentação do Liberal Pernambucano esmaecida na posteridade e as palavras do cônsul inglês afogadas no meio de outras tantas denúncias sobre o tráfico. Aqueles senhores de engenho aparentados de senadores do império saíram impunes da sua participação direta no tráfico. Era em seus engenhos que aportavam os navios negreiros. Até o guabiru-mor Araújo Lima, o ex-regente e Marquês de Olinda, aparece menor do que realmente era na obra de Joaquim Nabuco. Certamente porque, como vimos, tornou-se um encarniçado inimigo do seu pai, como disse o padre Pinto de Campos a Pedro (Visconde de Camaragibe), o mais jovem dos três irmáos Cavalcanti no senado imperial. Já os praieiros, táo elogiados por Mr. Christophers pelo combate ao tráfico, continuaram esmagados pelas palavras de um filho abolicionista, biógrafo do pai escravagista. A versão de Joaquim Nabuco venceu. $\mathrm{O}$ episódio ficaria praticamente esquecido. As malhas do poder oligárquico que ligavam o desembarque até a corte continuariam intocadas. Esse artigo mostra que o gabinete da conciliação não estava isento de ligaçôes com o tráfico e que o campo conservador estava fraturado, mesmo que se unissem solidamente para combater seus adversários na política imperial. A missão do gabinete da conciliação era estancar o tráfico também "conciliando", ou seja, livrando seus aliados da puniçáo. Talvez o melhor resumo da hipocrisia latente nesse episódio esteja numa frase largada pelo deputado Pinto de Campos em mais uma de suas cartas de fofoca política a seu chefe Cavalcanti (Pedro, o Visconde de Camaragibe): "Cada vez me convenço mais de que a política é a arte de matar a vergonha!"90

\footnotetext{
${ }^{89}$ NABUCO, Joaquim. Um estadista do Império, op. cit., p. 238.

${ }^{90}$ IAHGP - FVC - Caixa 1. Carta do Padre Pinto de Campos ao Visconde de Camaragibe, Rio de Janeiro, 13/06/1855.
} 


\section{Fontes}

ARQUIVO DA FACULDADE DE DIREITO DO RECIFE (AFDR). Correspondências expedidas (1830-1838), n. 1.481. Documento n. 3, outubro de 1837.

ARQUIVO HISTÓRICO DO ITAMARATY (Rio de Janeiro). Comissóes Mixtas, Escuna Cacique.

ARQUIVO NACIONAL, Rio de Janeiro (ANRJ). Justiça, IJ6 - 521 e IJ6 522.

ARQUIVO PÚBLICO ESTADUAL JORDÃO EMERENCIANO. Avisos Reservados, vol. 1. Falas do trono. São Paulo: Instituto Nacional do Livro-MEC/Melhoramentos, 1977, p. 171, 184.

HEMEROTECA DIGITAL DA BIBLIOTECA NACIONAL (HDBN). Annaes do Parlamento Brazileiro - Câmara dos Senhores Deputados. Rio de Janeiro: Typographia de Hyppolito José Pinto \& Ca, 18, sessões de 1853, 1855, 1856. Diário de Pernambuco, 30/07/1866. Diário Novo, Recife, 31/01/1846. Echo Pernambucano, Recife, 21/01/1851, 25/04/1851. O Carapuceiro, Recife, 23/03/1839. O Liberal Pernambucano, Recife, 18/10/1855, 12/03/1856, 18/06/1856, 27/06/1856, 14/07/1856, 17/12/1856, 20/02/1857, 21/02/1857, 22/02/1857, 24/02/1857, 25/02/1857, 26/02/1857, 27/02/1857, 28/02/1857, 02/03/1857.

INSTITUTO ARQUEOLÓGICO, HISTÓRICO E GEOGRÁFICO PERNAMBUCANO (IAHGP). A Imprensa, Recife, 17/12/1850. Fundo Visconde de Camaragibe (FVC) - Caixa 1. National Archives (Londres): Foreign Office, Caixa 315/69.

PARLIAMENTARY PAPERS, House of Commons, Slave trade, Class A, B, C e D, vols. 26, 28, 32, 33, 42 e British and Foreign State papers, 1850-1851, v. XL. https://www.proquest. $\mathrm{com} /$ researchers/student-general-researcher/

UNIVERSIDADE DE CHICAGO: Center for Research Libraries, Brazilian Government Documents Relatório de José Bento da Cunha Figueiredo, 05/05/1850, fl. 1. http://brazil. crl.edu/bsd/bsd/16/000003.html.

\section{Referências}

BETHELL, Leslie. The abolition of the Brazilian slave trade, Cambridge, Cambridge University Press, 1970.

CADENA, Paulo Henrique Fontes. O vice-rei: Pedro de Araújo Lima e a governança do Brasil no século XIX. Tese (Doutorado em História Social). Programa de Pós-Graduação em História - UFPE, Recife, 2018. 
CARVALHO, José Murilo. A construção da ordem. Rio de Janeiro: Campus, 1981.

CARVALHO, Marcus J. M. de. O desembarque nas praias: o funcionamento do tráfico de escravos depois de 1831. Revista de História, São Paulo, n. 167, p. 223-260, 2012.

CASCUDO, Luis da Câmara. O Marquez de Olinda e seu tempo (1793-1870). São Paulo: Companhia Editora Nacional, 1938.

COSTA, Valéria Gomes. O Recife nas rotas do Atlântico negro: tráfico, escravidão e identidades no oitocentos. Revista de História Comparada, Rio de Janeiro v. 7, 1, p. 186217, 2013.

DOMINGUES DA SILVA, Daniel e ELTIS, David. The slave trade to Pernambuco, 15611851. In: ELTIS, David e RICHARDSON, David (eds.). Extending the frontiers: essays on the New Transatlantic Slave Trade Database. New Haven: Yale University Press, 2008, p. 95-129.

EISENBERG, Peter. Modernização sem mudança. Rio de Janeiro: Paz e Terra, 1977.

ESTEFANES, Bruno Fabris. Conciliar o Império: Honório Hermeto Carneiro Leão, os partidos e a política de conciliação no Brasil monárquico (1842-1856). Dissertação (Mestrado em História Social) - Programa de Pós-Graduação em História Social - USP, São Paulo, 2010

FERREIRA, Roquinaldo Amaral. Dos sertóes ao Atlântico: tráfico ilegal de escravos e comércio lícito em Angola, 1830-1860. Dissertação (Mestrado em História Social) - Programa de PósGraduação em História Social - UFRJ, Rio de Janeiro, 1996.

GONSALVES DE MELLO, José Antonio (org.). O Diário de Pernambuco e a história social do Nordeste, Recife, Cruzeiro, 1975.

GRADEN, Dale T. O envolvimento dos Estados Unidos no comércio transatlântico de escravos para o Brasil, 1840-1858. Afro-Ásia, Salvador: CEAL/UFBA, v. 35, 2007, p. 9-35. HORNE, Gerald. O Sul mais distante: os Estados Unidos e o tráfico de escravos africanos. São Paulo: Companhia das Letras, 2010.

MATTOS, Ilmar Rohloff de. O tempo saquarema. São Paulo, Hucitec, 2004.

MOSHER, Jeffrey. Political struggle, ideology, and State building: Pernambuco and the construction of Brazil, 1817-1850. Lincoln \& London: University Nebraska Press, 2008.

NABUCO, Joaquim. Um estadista do Império: Nabuco de Araújo, sua vida, suas opinióes, sua época. V. 1. Rio de Janeiro: Garnier, 1897.

Nabuco de Araújo, José Tomaz. Justa apreciação do predomínio praieiro ou história da dominação da praia. (Recife, 1847), Recife, Secretaria de Educação e Cultura, 1977.

NEEDELL, Jeffrey. The party of order: the conservatives, the State and slavery in the Brazilian Monarchy, 1831-1871. Stanford: Stanford University Press, 2006. p. 163-164.

QUINTAS, Amaro. O sentido social da Revolução Praieira. Recife, UFPE, 1977. 
SISSON, S.A. Galeria dos brasileiros ilustres. V. I e II. Brasília: Senado Federal, 1999.

TAUNAY. O Senado no Império. 1891. Brasília: Senado Federal, 1978.

VALENCIA VILLA, Carlos e FLORENTINO, Manolo. Abolicionismo inglês e tráfico de crianças escravizadas para o Brasil, 1810-1850. História, São Paulo, v. 37, p. 1-20, 2016.

VEIGA, Gláucio. O desembarque de Sirinhaém. Estudos, Recife: Editora Universitária, 1977. 